\title{
Personality Profiles Using MBTI Test for Sport Talent Identification for Students
}

\author{
$1^{\text {st }}$ Donny Wira Yudha Kusuma \\ Physical Education Department \\ Universitas Negeri Semarang \\ Semarang, Indonesia \\ donnywirayudhakusuma@mail.unnes.ac.id
}

\author{
$2^{\text {nd }}$ Hermawan Pamot Raharjo \\ Physical Education Department \\ Universitas Negeri Semarang \\ Semarang, Indonesia \\ hermawan_pamot@yahoo.com
}

\author{
$3^{\text {rd }}$ Mugiyo Hartono \\ Physical Education Department \\ Universitas Negeri Semarang \\ Semarang, Indonesia \\ mugiyohartono@mail.unnes.ac.id
}

\begin{abstract}
Making an accurate and valid prediction about an athlete's long term success in professional sport is likely a difficult aspect of professional coaches' role. To date however, personality inventories have yet to become common place within this evaluative process; and thus, their predictive utility within the talent identification process has not yet been adequately tested [1]. This study described of personality profile for talent identification for elementary and junior high school students in Magelang. Myers Briggs Type Indicator (MBTI) used for measure a psychometric personality. 354 Students in Magelang (205 male, 149 female) filled out the MBTI. In present research work it was found that male students of elementary school were having a significantly higher preference of $I$ and $S$ than male students of junior school who were having preference of $T$ and $P$. Additionally it was found that the female students of elementary school were having a significantly higher only on attribute of $F$, than their female counterparts of junior students in whom $E, N$ and $J$ attribute was high. ESTJ type was found to be the dominant one in the Magelang students' population followed by ESTP type.
\end{abstract}

Keywords - talent identification, personality, student

\section{INTRODUCTION}

Knowing sports talent since early has many advantages. From an economic point of view, the success of the national sports industry relies heavily on the identification and development of successful athletic talent. For the year 20162017, The National Federation of State High School Associations [2] reports that 7.963.535 high school students participated in high school sports. While in Indonesia especially in Central Java, low status in physical activity of high school students [3]. These number indicates that less than $1 \%$ of all athletes participated at school will continue into college. Even fewer athletes will have the ability to become professional athletes [3,4]. For example, research has proven the positive effect of athletic participation in improving kinesthetic skills, social development, and academic outcomes $[5,7]$. Additionally, Sport is a promising setting for obesity prevention among youth $[8,9]$.

Athletic talent identification is of particular interest to coaches, researchers, parents, and educators alike. Some survey of elite young athletes found that parents were the strongest influence on the initiation of a sport (gymnastics, tennis, swimming, soccer) while coaches were the strongest influence on their decision to perform intense training [10]. Research findings suggest that student athletes who perceive they have high ability levels are more likely to maintain participation in sports activities $[10,11]$.

Physical education (PE) teachers are the first to identify talented students [12]. While, some study found the majority of subject leaders claimed to identify talented students according to their current levels of achievement, whilst only a small percentage based identification upon students' potential to achieve. The most common criteria for assessment were a performance in school sport and club sport. Its indicated that the

\section{Methodology}

\section{A. Study Design and Sampling Procedure}

The method used in this research is survey method with ex post facto research design. This is used to determine the personality profile of students in Magelang, Central Java. A total of 354 students (251 elementary, 103 junior, 205 males, and 149 females) composed the sample. All individuals were informed about the objectives of the research and that data would only be used for research purposes and generally analysed, and they signed a consent form to participate in this study. Samples obtained students from 14 districts in Magelang.

\section{B. Instrument Development and Data Collection Procedure}

The instrument used was the reviewed Indonesian version of the Myers Briggs Type Indicator (MBTI) containing 60 questions. The MBTI involves 8 different personality "preferences." The preferences are organized into 4 dichotomies (contrasting categories) with subcategories rating key aspects of personality, including styles of perception (P), sensing (S), intuition $(\mathrm{N})$, judgment $(\mathrm{J})$, feeling $(\mathrm{F})$, extraversion (E) and introversion (I). And being applied just once, and also have 0,6 to 0,8 scale reliabilities [13]. 


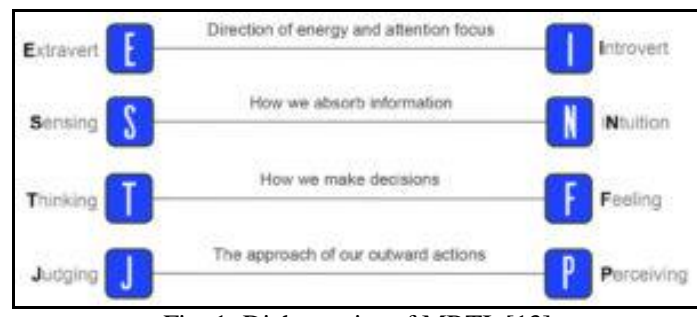

Fig. 1: Dichotomies of MBTI [13]

Procedure Questionnaires were administered to subjects within 15-20 minutes and the nature of study was described at the top of the questionnaire to the subjects. Participant filled out a multiple choice question; there are no right or wrong answers. The MBTI instrument is not a test. Subject select the answers that best fit for them. Investigator collected the questionnaires from each $\mathrm{PE}$ teachers after completing the questionnaire.

\section{Data Processing and Analysis}

For the analysis of the personality profiles for students talent identification, the descriptive percentage analysis was initially used (average and standard deviation) for the behavior of each variable to be studied. In order to describe the data and differences the t-test was used. At the significance level of 0.05 was used in order to determine the differences between study groups. The statistical program used was the SPSS version 19.0

\section{RESULT AND DISCUSSION}

The socio-demographic sample is shown in Table 2, i.e.: the total number of samples of 354 students (251 elementary, 103 junior, 205 males, and 149 females).

TABLE I. : : GENERAL CHARACTERISTICS OF THE SAMPLE.

\begin{tabular}{|l|c|c|c|c|c|c|}
\hline \multicolumn{1}{|c|}{ Districts } & SD & SMP & Total & M & F & Total \\
\hline Tegalrejo & 19 & 0 & 19 & 13 & 6 & 19 \\
\hline Secang & 20 & 0 & 20 & 2 & 18 & 20 \\
\hline Borobudur & 19 & 0 & 19 & 10 & 9 & 19 \\
\hline Bandongan & 19 & 0 & 19 & 15 & 4 & 19 \\
\hline Mungkid & 20 & 41 & 61 & 24 & 37 & 61 \\
\hline Ngluwar & 11 & 0 & 11 & 5 & 6 & 11 \\
\hline Muntilan & 0 & 21 & 21 & 13 & 8 & 21 \\
\hline Mertoyudan & 0 & 19 & 19 & 15 & 4 & 19 \\
\hline Salaman & 20 & 22 & 42 & 30 & 12 & 42 \\
\hline Tempuran & 21 & 0 & 21 & 10 & 11 & 21 \\
\hline Candimulyo & 21 & 0 & 21 & 16 & 5 & 21 \\
\hline Salam & 21 & 0 & 21 & 19 & 2 & 21 \\
\hline Magelang & 20 & 0 & 20 & 10 & 10 & 20 \\
\hline Kota Magelang & 40 & 0 & 40 & 23 & 17 & 40 \\
\hline \multicolumn{1}{|c|}{ Total } & 251 & 103 & 354 & 205 & 149 & 354 \\
\hline
\end{tabular}

Note: SD: elementary school; SMP: junior high school; M: male; F: female.

The foremost aim of the study was to identification of the data which was analyzed through percentage distribution. The table 2 reported of the percentage distribution personality profile of all 354 students. ESTJ (type was found to have the highest percentage in the total sample. And the least was INFJ and INTP type.

TABLE II. : THE PERCENTAGE DISTRIBUTION OF ELEMENTARY AND JUNIOR SCHOOL STUDENTS.

\begin{tabular}{|c|c|c|c|c|c|}
\hline \multirow{2}{*}{ Type } & \multicolumn{2}{|c|}{ SD } & \multicolumn{2}{c|}{ SMP } & \multirow{2}{*}{ Total } \\
\cline { 2 - 5 } & $\mathbf{M}$ & $\mathbf{F}$ & $\mathbf{M}$ & $\mathbf{F}$ & \\
\hline ISTJ & 2,8 & 2,5 & 0,8 & 1,1 & $7,3 \%$ \\
\hline ISFJ & 3,1 & 1,4 & 0,6 & 0,0 & $5,1 \%$ \\
\hline INFJ & 0,3 & 0,0 & 0,0 & 0,0 & $0,3 \%$ \\
\hline INTJ & 0,6 & 0,8 & 0,3 & 0,3 & $2,0 \%$ \\
\hline ISTP & 3,1 & 0,6 & 0,6 & 0,3 & $4,5 \%$ \\
\hline ISFP & 0,8 & 1,1 & 0,0 & 0,0 & $2,0 \%$ \\
\hline INFP & 0,3 & 0,3 & 0,0 & 0,0 & $0,6 \%$ \\
\hline INTP & 0,0 & 0,0 & 0,3 & 0,0 & $0,3 \%$ \\
\hline ESTP & 4,8 & 1,7 & 2,8 & 0,8 & $10,2 \%$ \\
\hline ESFP & 2,5 & 0,8 & 1,1 & 0,3 & $4,8 \%$ \\
\hline ENFP & 0,3 & 0,8 & 0,3 & 0,8 & $2,3 \%$ \\
\hline ENTP & 1,7 & 0,8 & 1,1 & 0,3 & $4,0 \%$ \\
\hline ESTJ & 9,9 & 9,6 & 6,5 & 5,6 & $31,6 \%$ \\
\hline ESFJ & 5,9 & 6,2 & 0,3 & 2,0 & $14,4 \%$ \\
\hline ENFJ & 2,5 & 1,4 & 0,0 & 0,3 & $4,2 \%$ \\
\hline ENTJ & 3,1 & 0,8 & 1,4 & 1,1 & $6,5 \%$ \\
\hline Total & $41,8 \%$ & $29,1 \%$ & $16,1 \%$ & $13,0 \%$ & $100 \%$ \\
\hline
\end{tabular}

From table 2 reported that the highest percentage of students in talent identification program were ESTJ's followed by ESTP and ISTJ serially. The percentage for the four respective dichotomies e.g. E/I, S/N, T/F and J/P showed on table 3. It's reported for each sample of gender for each school criteria.

TABLE III. : THE PERCENTAGE OF EIGHT PERSONALITY VARIABLE

\begin{tabular}{|c|c|c|c|c|c|c|}
\hline & \multicolumn{2}{|c|}{ SD } & \multicolumn{2}{c|}{ SMP } & \multirow{2}{*}{ Total } & \multirow{2}{*}{ P } \\
\cline { 2 - 5 } & $\mathbf{M}$ & $\mathbf{F}$ & $\mathbf{M}$ & $\mathbf{F}$ & & \\
\hline Extrovert (E) & 66,7 & 82,4 & 80,8 & 88,5 & 77,5 &, 000 \\
\hline Introvert (I) & 33,3 & 17,6 & 19,2 & 11,5 & 22,5 &, 021 \\
\hline Sensing (S) & 79,1 & 78,9 & 76,9 & 67,7 & 77,1 &, 000 \\
\hline Intuition (N) & 20,9 & 21,1 & 23,1 & 32,3 & 22,9 &, 003 \\
\hline Thinking (T) & 62,2 & 58,3 & 86,0 & 73,9 & 66,4 &, 002 \\
\hline Feeling (F) & 37,8 & 41,7 & 14,0 & 26,1 & 33,6 &, 017 \\
\hline Perceiving (P) & 32,4 & 21,4 & 38,6 & 19,6 & 28,5 &, 009 \\
\hline Judgment (J) & 67,6 & 78,6 & 61,4 & 80,4 & 71,5 &, 001 \\
\hline
\end{tabular}

Note: SD: elementary school; SMP: junior high school; M: male; F: female; p: sig. $(0,05)$

From the table 2 and table 3 showed the percentage of male and female students of elementary and junior schools were compared for the percentage points of their corresponding parameters of E/I, S/N, T/F and J/P:

The first dichotomies (direction of energy and attention focus) highest percentage of extrovert (E) was female student of junior school $(88.5 \%)$, and the lowest was male student of elementary school $(66.7 \%)$. And the highest percentage of introvert (I) was male students of elementary school $(33.3 \%)$ and lowest was female student of junior school (11.5\%). 
The second dichotomies (how to absorb information), male students of elementary school has highest percentage on sensing (S), and female students of junior school has high percentage on Intuition (N). Third dichotomies (how to make decision), the highest percentage on thinking (T) was male students of junior school, and feeling (F) was female students of elementary school. For the last dichotomies (approach of outward action), perceiving $(\mathrm{P})$ has highest percentage by male students of junior school, the contrary of sub-category was judgment $(\mathrm{J})$ by female students of junior school.

The psychology of personality is concerned with these individual differences. One approach involves looking at personality traits, stable aspects of personality with a partial genetic basis. The most influential trait theories are those of Eysenck, Cattell, and Costa and McCrae [14].

Today, many companies are asking their workers to take personality tests before they decide on the right job positions. This became a popular trend in the world of sports. Many trainers and sports organizations require athletes to take this type of test in order to find out if they will be good for their team and have the right character according to the sport they choose [15].

Various instruments for knowing one's personality have been researched by the researcher. The Myers Briggs Type Indicator (MBTI) [13,16]; the SPQ-20 (Myskillprofile,2016); Minnesota Multiphasic Personality Inventory (MMPI), the Sixteen Personality Factor Questionnaire (16PF), the Comrey Personality Scales (CPS), among many others [17, 18]; Dominant, influence, steadiness and conscientiousness or called by DiSC [19].

The MBTI is usually used in a company context and at times also in other areas where the psychometric analysis of personality traits, someone's abilities or the team constellations plays an important role. There is no specific MBTI for sports but we believe that people who play a certain sports might be more prone to be certain of the 16 MBTI types than another one. In reverse, this might help coaches to tailor training programs more individually and gives them a starting point of analysis and outline of possible solution in case a certain training method does not seem to work for some players. Becoming a better coach and creating a better team starts with awareness of whom they are coaching and the MBTI might contribute to that. In addition, having the information the MBTI provides you with at hand might help for recruiting of professional athletes as well as a better understanding between the teammates.

As reported from Table-2 out of the sixteen types of personality preference ESTJ (112/354) followed by ESFJ (51/354) and ESTP (36/354) were represented. If we look in more detail at the type preferences we will find that ES were having most dominant preference. Ghaderi \& Ghasemi, (2012) reported that team athletes are more extroverted (E) than individually athlete, and then individual athletes are more introverted (I) than team athlete. for the next dichotomies, athletes are more used sensing (S) than intuition $(\mathrm{N})$, but athletes that have high subjectivity has tendency more intuition (N) to absorb information [20,21].
The athlete can make decisions by two ways; by thinking and feeling. The research on semi-professional soccer player reported that soccer athletes are most used thinking for they make decision on playing soccer [22], but they need to used feeling when they shooting the ball to making goal.

The last dichotomies were the approach of outward action with judging or perceiving. The MBTI provides two final distinctions about how individuals approach life: structured or flexible by Myers \& McCaulley on [23]. Judgers approach life in a structured way, preferring matters to be settled, while perceivers like to keep decisions "open." Perceivers gain a sense of control by keeping their options open and making choices only when they are necessary. Aside from MBTI's extroversion and thinking constructs, little is definitive about how the other personality indicators may influence sport behavior.

Previous research has used dimensions of the big five personality model, as well as the MBTI, to identify personality differences among athletes and non-athletes [24, 25], but a growing body of research indicates that this information may also be useful in predicting sport choice as well. It's suggested that people with certain personalities are likely to choose sports that require behaviors matching their personalities. For example, LeUnes \& Nation, (1982) [26] linked thinking and feeling preferences with sport participation choices. Personality and cognitive style as predictor variables with each uniquely contributing to two facets of virtual team preference, namely preference for virtual teams over working alone and preference for virtual teams over traditional groups [27]. Thus, it's plausible to assume that individuals scoring high as thinkers would be more likely to engage in contact (direct) sports. It's also been hypothesized that extroverts will seek "direct" sports where aggression is permitted instead of sports where it is not [28]. This theory stems from an extroverted athlete's desire to seek greater levels of arousal more so than their introverted counterparts [29].

However, inconsistencies have occurred when attempting to analyze comparisons of "team-sport" athletes to "individualsport" athletes. Allen, Greenlees, \& Jones, (2013) revealed that athletes participating in team sports were more extraverted and open to new experiences, but less emotionally stable and conscientious than those competing in individual sports [30]. From an anecdotal standpoint, it would be reasonable to posit that individual athletes would be more introverted than team participants due to the private nature of their sport [30]. However, Aidman \& Schofield (2004) and Morgan \& Costill (1996) suggesting that athletes competing in different contexts may render heterogeneous findings $[1,31]$. Moreover, fewer differences in personality scores have been identified between athletes competing in various individual sports. Due to the conflicting findings of prior studies, this study sought to establish more reliable estimates of personality and sport choice.

\section{CONCLUSION}

An individual's interest to engage in an activity may be regulated by their level of satisfaction with the pursuit. Kandler et al., (2012) and Mann, Briley, Tucker-Drob, \& Paige Harden 
(2015) indicated that the development of normal personality may inform understanding of the genetic underpinnings of callous and unemotional behavior this internal regulation is reinforced by personal interests initiated by genetic influences $[32,33]$. But as Bergman (2012) indicated, "The internal motivators determined by your genetics still require development by practicing". From the results, it can concluded that the higher percentage of personality on students in Magelang were ESTJ (Extrovert; Sensing; Thinking; and Judgment) and the lowest were INTP (Introvert; Intuition; Thinking; and Perceiving) and INFJ (Introvert; Intuition; Feeling; and Judgment.

\section{ACKNOWLEDGMENT}

To all students and PE teachers in Magelang who voluntarily participated in the data collection and to the members of technical commissions of the following sportive modalities that enabled the performance of this study: chief of Disporapar Central Java and ranks.

\section{REFERENCES}

[1] E. Aidman and G. Schofield, "Personality and individual differences in sport," Sport Psychol. Theory, Appl. issues (2nd ed.)., vol. 60, no. 2014, pp. 22-47, 2004.

[2] NFSHSA, "2012-13 High School Athletics Participation Survey," 2013-2014 NFHS Handb., pp. 52-70, 2013.

[3] K. S. Soegiyanto., "Society Involvment in Sport Activity" IEEE Transl. Keikutsertaan Masyarakat dalam Kegiatan Olahraga, $J$. Media Ilmu Keolahragaan Indones., vol. 3, pp. 18-24, 2013.

[4] H. J. Gray and J. A. Plucker, “' She's a Natural ': Identifying and Developing Athletic Talent," vol. 33, no. 3, pp. 361-380, 2010.

[5] D. G. Collings and K. Mellahi, "Strategic talent management: A review and research agenda," Hum. Resour. Manag. Rev., vol. 19, no. 4, pp. 304-313, 2009.

[6] A. Abbott and D. Collins, "Eliminating the dichotomy between theory and practice in talent identification and development: Considering the role of psychology," J. Sports Sci., vol. 22, no. 5, pp. 395-408, 2004.

[7] D. T. Pearson, G. A. Naughton, and M. Torode, "Predictability of physiological testing and the role of maturation in talent identification for adolescent team sports," J. Sci. Med. Sport, vol. 9, no. 4, pp. 277-287, 2006.

[8] T. F. Nelson, S. D. Stovitz, M. Thomas, N. M. LaVoi, K. W. Bauer, and D. Neumark-Sztainer, "Do youth sports prevent pediatric obesity? A systematic review and commentary," Current Sports Medicine Reports, vol. 10, no. 6. pp. 360-370, 2011.

[9] L. Burrows and J. McCormack, "Sporting fat: Youth sport and the 'obesity epidemic,"' in Inclusion and Exclusion Through Youth Sport, 2013, pp. 125-137.

[10] N. Jayanthi, C. Pinkham, L. Dugas, B. Patrick, and C. LaBella, "Sports Specialization in Young Athletes: Evidence-Based Recommendations," Sports Health, vol. 5, no. 3, pp. 251-257, 2013.

[11] S. Y. Lim, S. Warner, M. Dixon, B. Berg, C. Kim, and M. Newhouse-Bailey, "Sport participation across national contexts: A multilevel investigation of individual and systemic influences on adult sport participation," Eur. Sport Manag. Q., vol. 11, no. 3, pp. 197-224, 2011.

[12] N. Lanzon and R. Attard, "Teachers ' attitudes towards talent searching programmes," pp. 3-5, 2018.

[13] Myers Briggs Foundation, "The Myers \&amp; Briggs Foundation MBTI ${ }^{\circ}$ Basics,” The Myers \& Briggs Foundation, 2016. [Online]. Available: http://www.myersbriggs.org/my-mbti-personalitytype/mbti-
basics/home.htm?bhcp=1\%0Ahttp://www.myersbriggs.org/mymbti-personality-type/mbti-basics/.

[14] M. Jarvis, Sport psychology: Routledge Modular Psychology. 2005.

[15] C. J. Gee, J. C. Marshall, and J. F. King, "Should coaches use personality assessments in the talent identification process? A 15 year predictive study on professional hockey players," Int. J. Coach. Sci., vol. 4, no. 1, pp. 1-10, 2010.

[16] P. Berry, C. Wood, and B. Thornton, "The Myers-Briggs Type Indicator as a Tool to Facilitate Learning Outcomes for Team Building in the Classroom," Coll. Teach. Methods Styles J., vol. 3, no. 4, pp. 13-20, 2007.

[17] G. J. Boyle, G. Matthews, and D. H. Saklofske, "Personality theories and models: An overview," SAGE Handb. Personal. Theory Assess. Vol. 1 - Personal. Theor. Model., pp. 1-30, 2008.

[18] G. J. Boyle, “A definitive, authoritative and up-to-date resource for anyone interested in the theories, models and assessment methods used for understanding the many facets of human personality and individual differences."

[19] R. Blake and D. Alais, "Research Report for Adaptive Testing Assessment DiSC," no. 1995, pp. 145-150, 2015.

[20] N. Ghaderi and A. Ghasemi, "The association between personal characters ( Extroversion, Introversion ) and emotional intelligence with choose type of sport ( team and individually )," vol. 2, no. 6, pp. 2038-2042, 2012.

[21] A. Reuter and J. Holder, "Traditional vs . Extreme Athletes: An Exploration of Personality Indicators Traditional vs . Extreme Athletes : An Exploration of Personality Indicators," Big Sky Undergrad. J., vol. 1, no. 1, pp. 1-18, 2013.

[22] L. Nelson, P. Potrac, D. Gilbourne, A. Allanson, L. Gale, and P. Marshall, "Thinking, Feeling, Acting: The Case of a SemiProfessional Soccer Coach,” Sociol. Sport J., vol. 30, no. 4, pp. 467-486, 2013.

[23] E. Hungenberg and J. Gould, "Serious Leisure and Personality Dimensions in Club Sport Athletes," Sport Soc., vol. 8, no. 2, pp. 164-181, 2015.

[24] M. D. Reiter, T. Liput, and R. Nirmal, "Personality Preferences of College Student-Athletes," Coll. Stud. J., vol. 41, pp. 34-36, 2007.

[25] M. Shariati and S. Bakhtiari, "Comparison of personality characteristics athlete and non-athlete student, Islamic Azad University of Ahvaz," Procedia - Soc. Behav. Sci., vol. 30, pp. 2312-2315, 2011.

[26] A. LeUnes and J. R. Nation, "Saturday's heroes: A psychological portrait of college football players.," J. Sport Behav., vol. 5, no. 3, pp. 139-149, 1982.

[27] A. Luse, J. C. McElroy, A. M. Townsend, and S. Demarie, "Personality and cognitive style as predictors of preference for working in virtual teams," Comput. Human Behav., vol. 29, no. 4, pp. 1825-1832, 2013.

[28] S. J. Mckelvie, P. Lemieux, and D. Stout, "Extraversion and Neuroticism in Contact Athletes, No Contact Athletes and Nonathletes : A Research Note," Athl. Insight - Online J. Sport Psychol., vol. 5, no. 3, pp. 19-27, 2003.

[29] H. J. Eysenck, "Creativity and Personality: Suggestions for a Theory," Psychol. Inq., vol. 4, no. 3, pp. 147-178, 1993.

[30] M. S. Allen, I. Greenlees, and M. Jones, "Personality in sport: A comprehensive review," International Review of Sport and Exercise Psychology, vol. 6, no. 1. pp. 184-208, 2013.

[31] W. P. Morgan and D. L. Costill, "Selected psychological characteristics and health behaviors of aging marathon runners: A longitudinal study," Int. J. Sports Med., vol. 17, no. 4, pp. 305-312, 1996.

[32] F. D. Mann, D. A. Briley, E. M. Tucker-Drob, and K. Paige Harden, "A behavioral genetic analysis of callous-unemotional traits and big five personality in adolescence," J. Abnorm. Psychol., vol. 124, no. 4, pp. 982-993, 2015.

[33] C. Kandler, L. Held, C. Kroll, A. Bergeler, R. Riemann, and A. Angleitner, "Genetic Links Between Temperamental Traits of the Regulative Theory of Temperament and the Big Five," J. Individ. Differ., vol. 33, no. 4, pp. 197-204, 2012. 